\title{
ON THE GLACIAL HISTORY OF ANTARGTICA*
}

\author{
By J. T. Hollin \\ (Institute of Polar Studies, The Ohio State University, Columbus, Ohio)
}

\begin{abstract}
The Antarctic Ice Sheet responds quickly to regime changes, and time lags in its fluctuations are relatively small. During the Pleistocene glacial stages of the Northern Hemisphere, world-wide temperature reductions reduced the plasticity of the ice sheet and made it thicker. The amount of thickening depended on the conditions at the ice base but it was small, for mechanical and thermal reasons. Also, during the northern stages, accumulation over Antarctica was probably less than now, but this too had little effect on the thickness of the ice sheet. The mass budget of the ice sheet alone, without the ice shelves, probably remained strongly positive; the ice sheet probably existed throughout the Pleistocene and is unlikely to disappear in the future. The area of the ice sheet is determined chiefly by the elevation of the "grounding line", where the peripheral ice cliffs and ice shelves begin to float. During the northern stages, world-wide lowerings of sea-level displaced the grounding line downwards and northwards, and allowed the ice sheet to advance by amounts which account for nearly all the evidence for previous greater glaciations. In summary, the glacial history of most ice-free areas is governed not so much by climatic as by sea-level changes. Therefore, Antarctic glacial fluctuations were dependent on and in phase with those of the Northern Hemisphere. The field evidence from Antarctica has little bearing on the ultimate causes of glacial fluctuations, which might however be determined by field work on the planet Mars.
\end{abstract}

RÉiumé. La calotte glaciaire de l'Antarctique répond rapidement aux changements de régime et les retards dans ses fluctuations sont relativement faibles. Pendant les étages glaciaires du Pléistocène dans l'hémisphère nord, les diminutions de température sur le globe entier réduisirent la plasticité de la calotte glaciaire et contribuèrent à l'augmentation de son épaisseur. Cette augmentation dépendait des conditions régnant à la base de la glace, mais elle était faible pour des raisons mécaniques et thermiques. Aussi, durant ces glaciations dans l'hémisphère nord l'accumulation dans l'Antarctique était probablement moindre que maintenant, mais néanmoins elle influencait légèrement l'épaisseur de la calotte glaciaire. Le bilan de masse de la calotte seule, c'est à dire sans les "ice shelves", restait sans doute fortement positif; la calotte glaciaire existait probablement pendant tout le Pléistocène et ne menace pas de disparaître dans l'avenir. La superficie de la calotte glaciaire est principalement déterminée par l'altitude de la "grounding line" où les falaises de glace et les "ice shelves" périphériques commencent à flotter. Pendant ces glaciations du nord, les abaissements du niveau de la mer déplaçèrent la "grounding line" vers le bas et vers le nord et permirent à la calotte glaciaire d'avancer en conséquence, ce qui explique la plus grande extension des glaciations antérieures plus importantes. En résumé, l'histoire glaciaire de la plupart des étendues libres de glace est régie davantage par les variations du niveau de la mer que par les variations du climat. Donc les fluctuations glaciaires de l'Antarctique dépendaient de celles de l'hémisphère nord et étaient en phase avec elles. Les preuves recueillies dans l'Antarctique, sur le terrain, ont une faible importance dans l'explication des dernières causes de fluctuations glaciaires, qu'il serait peut-être possible de déterminer en travaillant sur la planète Mars.

Zusammenfassung. Der antarktische Eisschild reagiert schnell auf Haushaltsänderungen; Verzögerungen in seinen Schwankungen sind verhältnismässig klein. Während der Vereisungen auf der nördlichen Halbkugel im Pleistozän verringerte der weltweite Temperaturrückgang die Plastizität des Eisschildes und liess ihn anwachsen. Der Betrag der Aufhöhung hing von den Bedingungen am Sockel des Eises ab, doch muss er aus mechanischen und thermischen Gründen klein gewesen sein. Während der Eiszeiten im Norden war die Akkumulation über der Antarktis vermutlich geringer als heute, aber auch dadurch wurde die Dicke des Eisschildes nur unwesentlich beeinflusst. Der Massenhaushalt des Eisschildes allein, ohne die Eisschelfe, blieb wahrscheinlich stark positiv; der Eisschild existierte vermutlich während des ganzen Pleistozän und läuft kaum Gefahr. in naher Zukunft zu verschwinden. Die Ausdehnung des Eisschildes ist vor allem durch die Höhenlage der "grounding line" bestimmt, an der die randlichen Eiskliffe und -schelfe zu schwimmen beginnen. Während der nördlichen Eiszeiten wurde die "grounding line" durch das weltweite Absinken des Meeresspiegels nach unten und nordwärts versetzt. Der Eisschild konnte dadurch um Beträge vorstossen, auf die beinahe alle Zeugnisse für frühere grössere Vereisungen zurückzuführen sind. Zusammenfassend kann man feststellen, dass die glaziale Geschichte der meisten eisfreien Gebiete mehr von Meeresspiegel-als von Klimaschwankungen bestimmt ist. Deshalb waren die Schwankungen der antarktischen Vereisung abhängig von denjenigen auf der Nordhalbkugel und phasengleich mit ihnen. Die Ergebnisse von Felduntersuchungen in der Antarktis können nur wenig zur ursächlichen Klärung von Gletscherschwankungen beitragen. Sie könnte indessen eher durch Feldarbeiten auf dem Planeten Mars gewonnen werden.

\section{INTRODUCTION}

\section{The problem}

Recent papers on Antarctica, particularly those of Péwé (1960), Nichols (I96 I [a]), and Bull and others (1962), suggest that the ice cover there has fluctuated several times during the Pleistocene. Obviously it is important to determine the history and extent of these fluctuations, to decide how they were related to those of the Eurasian and North American ice sheets, and to calculate the sea-level changes they produced. However, these are difficult problems to

* Contribution No. 8, Institute of Polar Studies, The Ohio State University, Columbus, Ohio. 
solve, chiefly because of the small area of the ice-free land available for geological field work. Indeed, the best record of Antarctic glaciation may in the end be found in the oceanic sediments outside the continent.

This paper represents a glaciological approach to these problems. In Section II the present mass budget and mechanics of the ice sheet are reviewed; this is a simple section but the information and conclusions in it are essential to the rest of the paper. Sections III, IV and $\mathrm{V}$ treat theoretically the fluctuations produced in Antarctica by the world-wide changes of

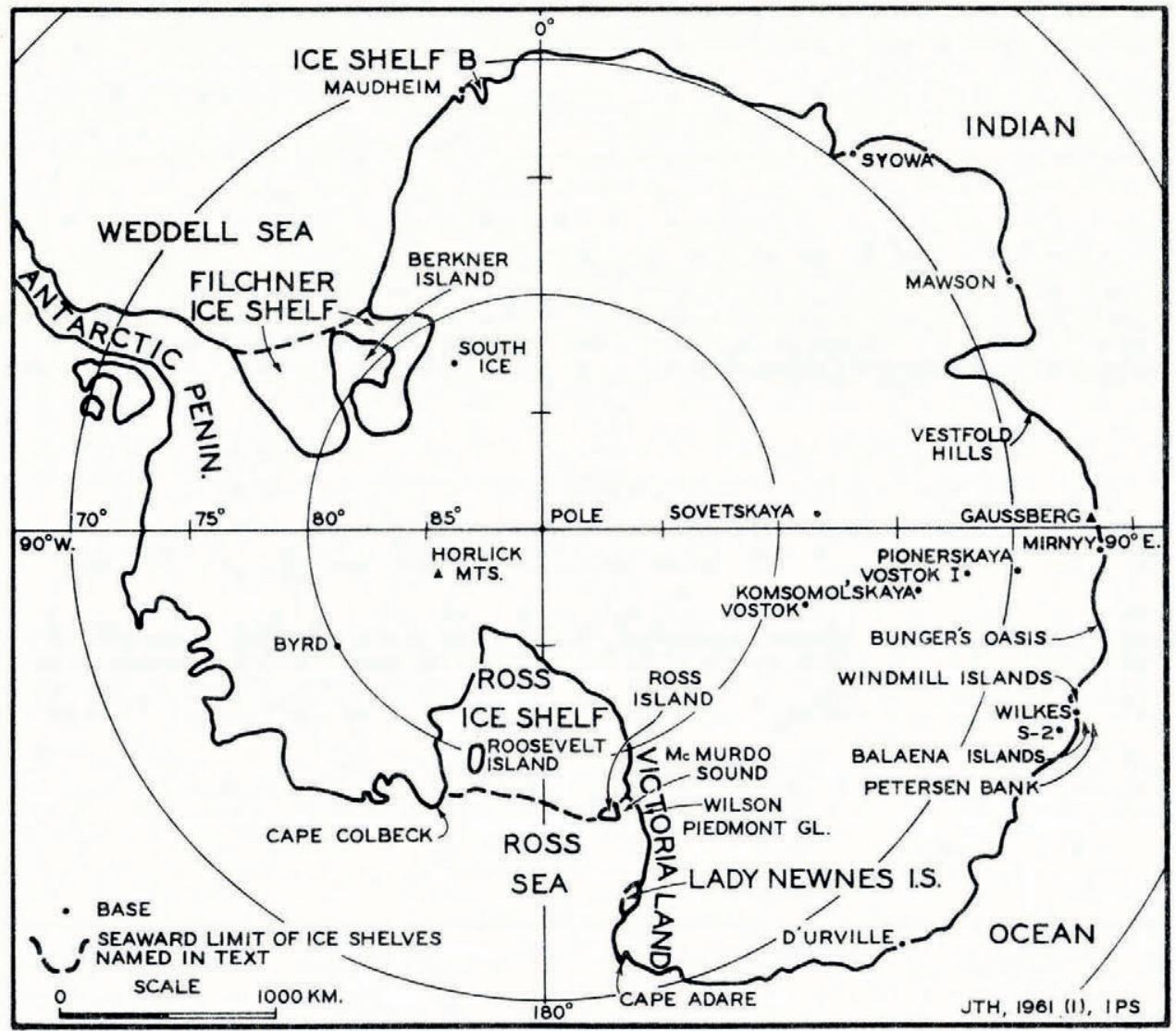

Fig. I. Antarctica, showing places named in text

temperature, precipitation and sea-level associated with the glacial fluctuations of the Northern Hemisphere. Section VI is concerned with changes unrelated to those of the Northern Hemisphere. The chief conclusion of this paper is that the greatest glacial fluctuations in Antarctica were produced by changes of sea-level; this conclusion is reached in Section V, and this part of the paper may be the most interesting one for field workers.

2. The unimporlance of time lags

The major glacial fluctuations in the Northern Hemisphere had a periodicity of the order of $100,000 \mathrm{yr}$. It is shown in this paper that the major fluctuations in Antarctica had a similar periodicity; therefore, the warning by Roots (1952) that "the lag between climatic change and change in the form of the glacier may be longer than the period of climatic change itself" can be ignored, and the maxima and minima in the fluctuations can be considered as steady states. In detail, there are three reasons for this: 
(a) Fifty thousand years is more than enough time for the ice sheet to "build up" from a minimum to a maximum state. The average annual accumulation in Antarctica is approximately I $4 \mathrm{~g} . / \mathrm{cm} .^{2}$ (mean of 7 values quoted by Wexler (I96I)); since the average thickness of the ice sheet is approximately $2,300 \mathrm{~m}$. (Bauer, $196 \mathrm{I}$ ) this could, ideally and ignoring ablation, be built up even from ground level in less than I 5,00o yr. In fact, in the marginal areas where glacial fluctuations were greatest, the accumulation is greater and the thickness less than quoted above, ablation is small, and any adjustment could be made in even less time. (The converse problem of the time taken to "ablate down" the ice sheet from a maximum to a minimum has been treated by various workers, e.g. Shumskiy (1957) for Bunger's Oasis, and Mellor (r959[a]) for the area inland from Mawson.)

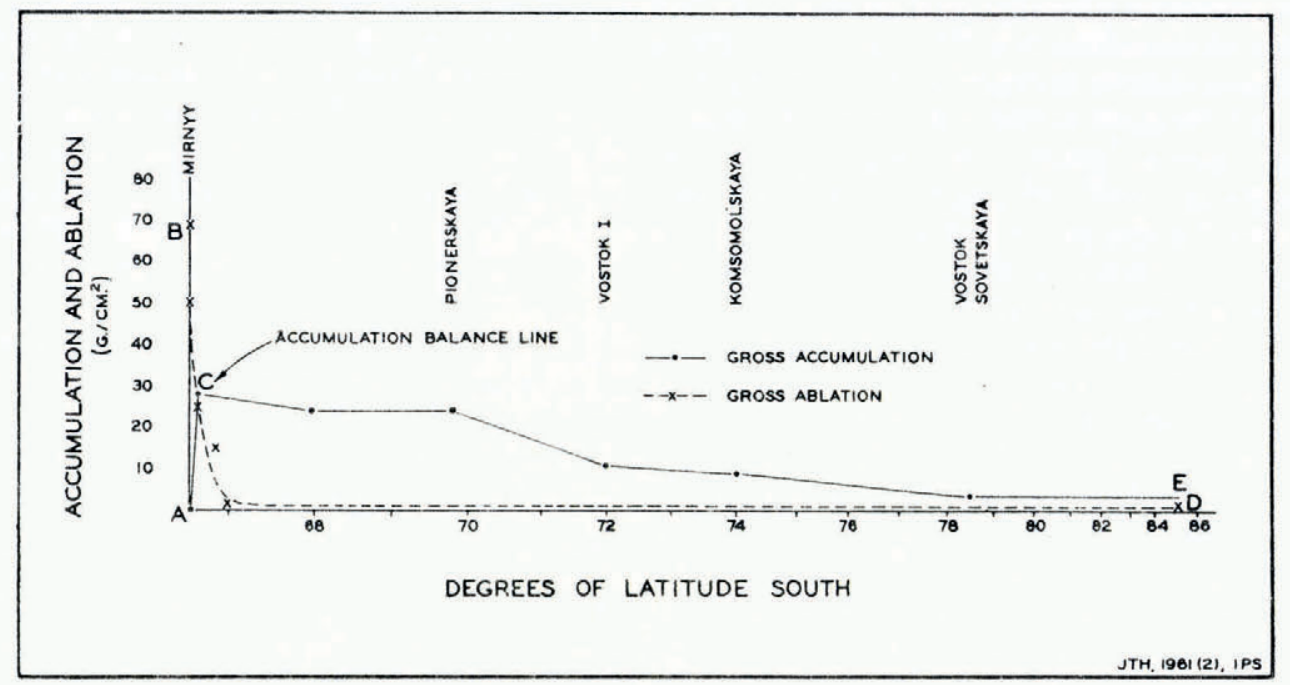

Fig. 2. Regime diagram of the ice sheet

(b) In practice, a glacier does not respond to a disturbance simply by building up or ablating down to a new equilibrium. The complex mechanical adjustment that probably occurs has been analyzed by Nye (1960), who has shown that a large-scale perturbation of even the whole Antarctic Ice Sheet should last for only 5,00o yr.

(c) According to Weertman (196I), the Antarctic Ice Sheet is exempt from that mechanical instability which may prevent other ice sheets from ever reaching steady states

\section{The Present Antarctic Ice Cover}

The distinction is emphasized between the main, grounded ice sheet of Antarctica with a convex profile and the peripheral, floating ice shelves with horizontal profiles. The difference in profiles is due to a difference in stress conditions and its importance is discussed on page 186.

I. The mass budget

(a) The grounded ice sheet

Figure 2, which is patterned on the regime diagrams of Ahlmann (1948, fig. 33), illustrates the mass budget of the grounded ice sheet. Gross accumulation (precipitation, condensation, sublimation, refrozen running water or "run-on", and the net balance of blown snow) and gross ablation (sublimation, evaporation and run-off) are plotted against the distance from the edge of ice sheet. A conservative view of the budget has been taken; accumulation and ablation values have been taken from the continent's Indian Ocean sector, where strong and persistent katabatic winds both reduce accumulation (by blowing much snow out 
of the continent) and increase ablation (by intensive sublimation and evaporation). The distance from the edge of the ice sheet is marked in degrees of latitude (since most of the data used come from the Soviet Antarctic Expedition the edge has been given the latitude of "Mirnyy" (lat. $66^{\circ} 33^{\prime} \mathrm{S}$.)) on a scale which contracts inland to allow for the fact that the area between parallels decreases as one approaches the South Pole. Because of the shortage of data the values illustrated have had to be taken from different parts of the Indian Ocean sector. The ablation values near the coast are from Mawson (Mellor, 1959[b]) and are based on stake measurements for three years. These values are gross because the strong winds of the ablation zone at Mawson prevent new snow from settling, which would make the figures net ones only. The $1.5 \mathrm{~g} . / \mathrm{cm} .{ }^{2}$ value at lat. $67^{\circ} \mathrm{S}$. is an estimate by Cronk (personal communication) based on a detailed analysis of three years of stake measurements at "Wilkes Station" and its auxiliary station S-2 (Hollin and Cameron, I96r). The $\mathrm{I} \mathrm{g.} / \mathrm{cm}^{2}$ value at lat. $85^{\circ} \mathrm{S}$. is the estimate of both Meinardus (reviewed by Loewe (1957)) and Lister (1959); obviously there is a need for more actual measurements of ablation in the interior. Gross accumulation values have been calculated by adding to the gross ablation curve net accumulation values from Shumskiy ( I960) and Dolgushin ( I96r). Probably because of the local topography, the Russian figures for the profile between the coast and lat. $68^{\circ} \mathrm{S}$. (up to $85 \mathrm{~g} . / \mathrm{cm} .^{2}$ ) seem atypically high. Therefore, for the purpose of this paper, gross accumulation values north of lat. $68^{\circ} \mathrm{S}$. have been plotted as follows:

(i) A straight line has been drawn from the value at lat. $68^{\circ} \mathrm{S} .\left(23 \mathrm{~g} . / \mathrm{cm} .^{2}\right.$ net accumulation plus I g./cm..$^{2}$ gross ablation) to the value at the "firn line" (actually the lower limit of the superimposed ice zone). The latter value is known because it must be equal to the gross ablation value, which can be obtained from the gross ablation curve. The firn line in this sector is here estimated to lie on the average $\mathrm{io} \mathrm{km}$. inland.

(ii) Because of the katabatic winds, gross accumulation (as defined at the beginning of this paragraph) on the steep slopes of these last $\mathrm{Io} \mathrm{km}$. decreases sharply. It has been assumed in Figure 2 that there is a linear decrease from the value at the firn line to zero at the coast.

The simplifications involved in Figure 2 are obvious. For example, to be fully useful in Section IV (p. 184), "the net balance of blown snow" should be separated into "snow blown in" and "snow blown out", and the latter entered in the gross ablation total. But in broad outline the Figure is probably correct. The significant feature of it is that the area CDE is roughly 50 times the area $A B C$. In other words, assuming a mass budget in equilibrium, about 98 per cent of the accumulation on the grounded ice sheet reaches the sea, and remains to be ablated by it, either directly from the coastal ice cliffs or indirectly from the floating ice shelves. This conclusion agrees roughly with those of Mellor (I959[b]) and Lister (I959); the former concludes that roughly ro per cent of the grounded ice sheet may be ablated before it reaches the sea; the latter thinks that ablation from the grounded ice sheet is not very significant at all. However, the strict quantitative accuracy of Figure 2 is not important. The main purpose of the Figure and the calculations above is to emphasize the overwhelming surplus in the budget of the grounded ice sheet. It appears now from both theory and movement studies that the Antarctic Ice Sheet is not, as it has so often been described, "static" or "sluggish" or "passive" but is in fact highly active. Indeed, its mean velocity around its periphery of roughly $15,000 \mathrm{~km}$. must be of the order of hundreds of meters per year.

It will be noticed that Figure 2 does include an ablation zone. Such a zone is ice-covered only because it is supplied with ice from "up-stream". As Avsyuk and others (1956) have pointed out, the share of this supply entering any particular part of the ablation zone depends on the subglacial relief at the firn line. Relatively high parts of the ablation zone, especially if they are flanked by deep valleys, form the ice-free areas or "oases" such as Vestfold Hills, Bunger's Oasis, the Windmill Islands and the mountains of south Victoria Land. However, over most of the periphery of Antarctica the supply of ice is great and the relief subdued, so that little of the ice is lost in the ablation zone and most of it reaches the sea. 
(b) Ice cliffs and ice shelves

The line where the ice sheet begins to float will be referred to as "the grounding line". Beyond this line the surplus of ice is exposed to the ablating influences of bottom melting and calving. Exactly what happens to the surplus depends on the thickness and velocity with which it reaches the coast and on the configuration of the coast and sea bed. For roughly half its margin the ice sheet terminates directly in the form of ice cliffs. Over the other half it pushes out to sea as a floating ice shelf. Eventually, even the ice shelves are limited by calving. This appears to be an extremely efficient ablating process and it is doubtful whether any ice shelf can exist beyond the limits of the relatively shallow continental shelf. This point has been developed by Swithinbank (1 955), who has shown how important to ice shelves are grounding points or anchors of rock at their seaward margins.

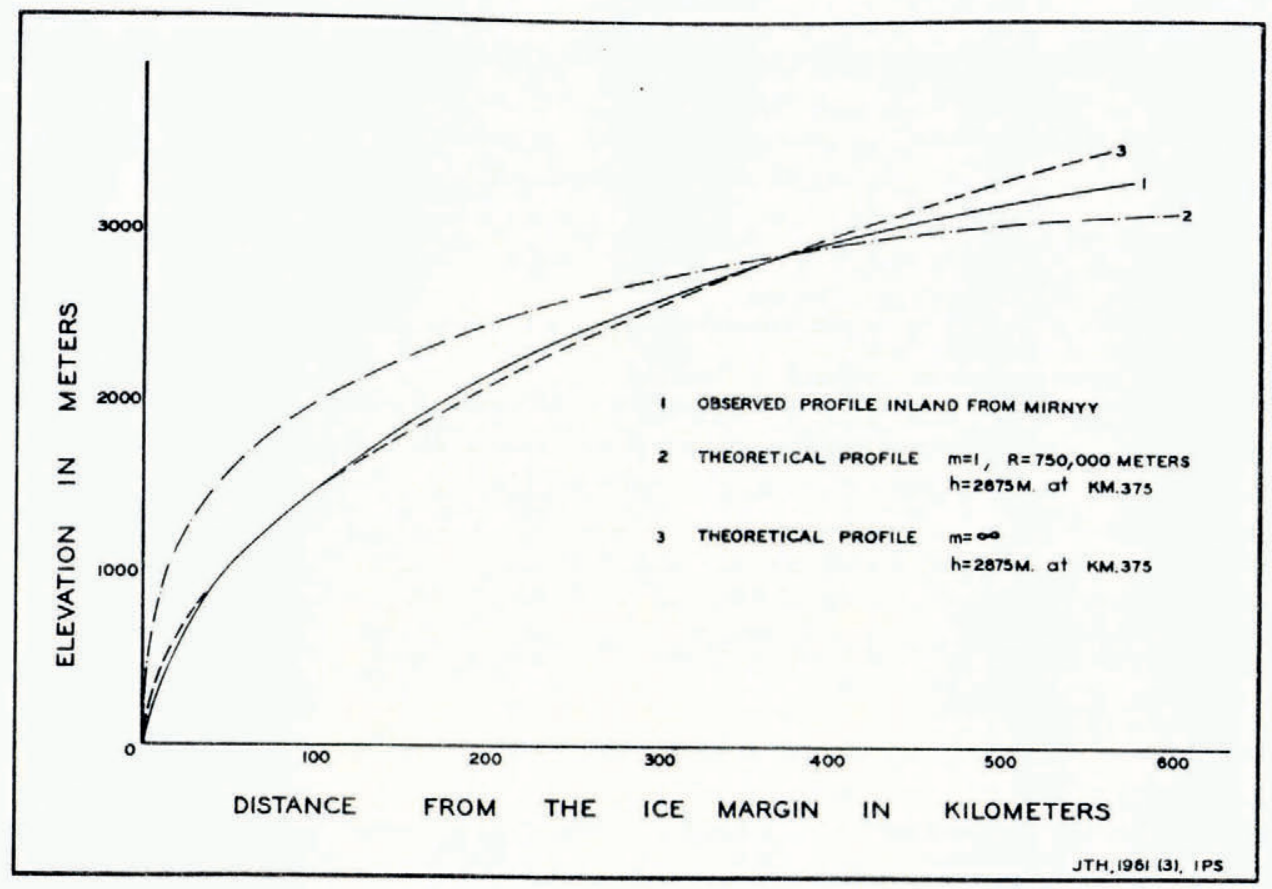

Fig. 3. Observed and theoretical profiles of the ice sheet

\section{The profile}

(a) The grounded ice sheet

The surface of the grounded ice sheet has a convex profile which is roughly similar from place to place. The profile illustrated in Figure 3 is that inland from "Mirnyy", where most data are available; it has been drawn, as far as possible, along a line of maximum slope, using the American Geographical Society map of Antarctica, and the Soviet map which accompanies an article by Dolgushin (1958). This and other profiles have been discussed by various authors, especially by Vyalov (1958). They are discussed briefly below, in the light of a recent paper by Nye (I 959), whose treatment is particularly suitable for use in Sections III and IV. Nye's main conclusion is that, because the temperature of a polar ice sheet is highest at the base (due to geothermal and frictional heating) and because the plasticity of ice increases strongly with temperature, nearly all the "relative motion of the ice sheet, whether between ice and ice, or between ice and rock, is essentially concentrated at the bottom". On this assumption he establishes the following law of sliding:

$$
u=(\tau / A)^{m} \text {, rewritten here as } u=A^{-m} \tau^{m}
$$


and combines this equation with the following

$$
\begin{aligned}
& a x / 2=h u \\
& \tau=\rho g h x
\end{aligned}
$$

to obtain a general expression for the profile of a circular (three-dimensional) ice sheet on a horizontal base:

$$
h^{2+1 / m}=\frac{2 m+\mathrm{I}}{m+\mathrm{I}} \cdot \frac{A}{\rho g}\left(\frac{a}{2}\right)^{1 / m}\left(R^{1+1 / m}-x^{\mathrm{I}+1 / m}\right)
$$

where $a=$ the accumulation rate, assumed uniform over the whole sheet, $x=$ the distance from the center of the sheet, $h=$ the thickness of the ice at any point, $u=$ the horizontal velocity (assumed uniform with depth) of the ice at any point, $\tau=$ the shear stress at the bed, $\rho=$ the density of the ice sheet, $g=$ the acceleration due to gravity, $\alpha=$ the maximum surface slope at any point $=-d h / d x$ (right-hand half of the ice sheet), $R=$ the radius of the ice sheet, and $A$ and $m$ are constants, discussed below.

$m$, analogous to the exponent $n$ in Glen's flow law (equation (6)), is probably 4.2 (Glen, ${ }_{1958)}$ in the case of motion between ice and ice, which is probably the movement mechanism where the ice base is below freezing (see the theoretical discussion by Weertman (1957[a]) and field observations by Goldthwait (in press)); and 2.5 in the case of motion between ice and rock, which may be a major movement mechanism where the ice base is at the melting point (see Weertman's ( $1957[\mathrm{a}]$ ) sliding model).

$A^{-m}$, assumed uniform under the whole sheet, is a constant which allows fer the conditions at the bed, where motion takes place. It may be considered as a function of four other quantities, $Z, Y, X$ and $W$, dependent on the roughness of the bed, the constitution and temperature of the ice, and on the wetness at the bed. Little is known about the effect of roughness; it is perhaps important only when the ice is at the melting point and sliding; then it may vary considerably with position but not with time (with which this paper is concerned). On the constitution of the ice, it is likely that the application of a roughly uniform shear stress for thousands of years over hundreds of kilometers produces near the bed a fairly uniform type of ice. For the purpose of this paper the most important variations in $A^{-m}$ are likely to be produced by changes in the temperature and wetness at the base, and these are discussed in Section III.

Equation (4) may be used to discuss briefly the observed profile of Figure 3. Unfortunately it is impossible to compare a curve derived from the equation directly with that of the figure, since the former has to be based on assumptions which are certainly not true: that the ice base is horizontal, $Z, X$ and $W$ are constant, and the accumulation is uniform. However, whereas curves for $m=\mathrm{I}$ and any reasonable value of $R$ are all too elliptical and give a profile which is much too steep at the edge and too flat at the center (Fig. 3), by putting $m=\infty$ one can obtain a parabola

$$
h=4.7 \sqrt{ } d
$$

(when $d$ is the distance from the edge of the ice sheet, and both $d$ and $h$ are expressed in meters), which fits almost exactly the observed profile as far as km. 375 (near "Pionerskaya", Fig. 3). This parabola happens to be the profile of a perfectly plastic ice sheet with a yield stress of I. o bar (Nye, 1952). That it fits so well is an argument for saying that $m$ is relatively large, probably not less than $2 \cdot 5$. Because it is so simple, equation (5) is used in Section V for the reconstruction of former ice profiles. (Beyond km. 375 this theoretical parabola rises above the observed ice surface. This may be lower for a variety of reasons, of which the most likely is that, because $m$ is in fact finite, the lower velocities needed near the center of the ice sheet can be produced by lower shear stresses. Moreover, these lower velocities are in fact very much lower, because the accumulation in the interior is so small.)

(b) Ice cliffs and shelves

Turning now to the margin of the grounded ice sheet, this normally reaches the sea and 
forms an ice cliff. The height of this cliff rarely exceeds $30 \mathrm{~m}$. and it is presumably limited by mechanical factors (although the theory on this subject is still uncertain (Loewe, 1955)). Therefore, even where the ice sheet has sufficient mass to push out into deep water, the total thickness of its margin can rarely, once it begins to float, exceed $200 \mathrm{~m}$. or so. If the supply from the grounded ice sheet is initially thicker than $200 \mathrm{~m}$. then the cliff will, unless it is maintained by extremely vigorous calving, spread out into a floating ice shelf, which may spread seaward for any distance between a fraction of a kilometer and hundreds of kilometers. The thickness of ice shelves has been discussed by Robin (1958), who has shown that "an approximate equilibrium thickness is maintained at a given locality" and that this thickness depends on, in order of importance, horizontal forces at the edges and grounding points and on the local temperature and accumulation. (The horizontal forces are the reason why large ice shelves are actually much thicker than $200 \mathrm{~m}$. in their landward parts.) One would expect, from the magnitude of $m$, that the thickness is only partly dependent on the amount or velocity of the supply from the grounded ice sheet. This supply must spread out quickly to the equilibrium thickness for the area offshore and its velocity must be transmitted to the whole shelf.

It can be seen now that for budgetary reasons the supply of ice on the grounded ice sheet is normally sufficient for it to reach the grounding line, but that for mechanical reasons the ice sheet cannot push beyond that line without being transformed into a floating ice shelf. It follows from this that the boundary of the grounded ice sheet is determined chiefly by the position of the grounding line and therefore by sea-level. The implications of this are the subject of Section V.

\section{The Effect of Changes in Air Temperature}

\section{The problem}

The idea that cooling can thicken glaciers by making them less plastic occurs frequently in glacial geological writings (on Antarctica see Nölke (I932)), although it has received little quantitative attention. Also, recent laboratory experiments have established quite clearly an effect of temperature on ice flow. Glen (1955) expresses this effect in the following flow law:

$$
\dot{\epsilon}=B \exp (-Q / R T) \sigma^{n} \text {, }
$$

where $\dot{\boldsymbol{\epsilon}}=$ the flow rate, $\sigma=$ the applied stress, $R=$ the gas constant, $T=$ the absolute temperature, and $B, n$ and $Q$ are constants. $Q$ is an activation energy. Assuming a constant stress, and for $Q$ a value of $16 \mathrm{kcal}$./mole (Butkovich and Landauer, 1958), a cooling from say $-3^{\circ}$ C. to $-9^{\circ}$ C. reduces the flow rate of ice by a factor of roughly 2 . Obviously it is important to establish whether or not such changes of flow rate are paralleled in glaciers by changes of thickness. The argument of this section is as follows. A probable chronology and amplitude for Pleistocene air temperature changes in Antarctica are established. It is argued that these changes were carried to the base of the ice sheet, where they changed its sliding velocity and hence its thickness. However, their total effect on ice thickness turns out to have been small.

\section{The changes}

\section{(a) Their chronology}

Consider first in what direction the temperature changed in Antarctica during the glacial fluctuations of the Northern Hemisphere. The theoretical answer to this problem depends partly on the unknown causes of Pleistocene temperature fluctuations. If these causes affected the whole world evenly then Antarctic fluctuations were probably in phase with those of the Northern Hemisphere. If the causes were localized in the Northern Hemisphere, as in the theory of Ewing and Donn (1956), Antarctic fluctuations were again probably in phase, though perhaps diluted. On the other hand, according to Milankovitch's well-known theory (reviewed by Flint ([r957], p. 508)) the causes of the fluctuations were not in phase in different hemispheres. However, wherever the causes of climatic change are localized, the atmospheric circulation works to spread their effects fairly uniformly over the whole globe; and Simpson. 
(1940), for example, has argued that because of this the temperature fluctuations of different hemispheres are forced to be in phase.

This theoretical argument is supported now by a large amount of field evidence. In New Zealand, radiocarbon dating of the Otira Glaciation suggests that this was contemporary with the northern Würm (Weichsel, Wisconsin) Glaciation (Gage, I96I). In Antarctica itself four types of evidence suggest that a twentieth century warming there has paralleled that in the Northern Hemisphere.

(i) As part of the I.G.Y. program numerous snow pits and cores were dug and drilled in Antarctica, and these have yielded information on the climate for several hundred years past. Most of these investigations are still in progress; however, Giovinetto (196o[b]) has reported at the South Pole thicker crusts which suggest warmer summers in the last $50 \mathrm{yr}$., and Cameron (personal communication) has reported at S-2, "Wilkes Station", thickened ice layers which may suggest the same.

(ii) Mellor (1960) has shown that a recent climatic warming provides the best explanation of a downward decrease of temperature measured in the upper $40 \mathrm{~m}$. of the ice sheet south of Mawson.

(iii) In the same paper Mellor discusses air temperature changes actually measured by the Antarctic expeditions of the twentieth century. A similar discussion has been published by Wexler (1959). Both suggest a warming.

(iv) A recent thinning of the Antarctic Ice Sheet has been reported from at least three places: by Hollin and Cameron (I96I) (snow patches at "Wilkes Station"), by Yoshikawa and Toya (1957) (snow patches at "Syowa") and by Shumskiy (r959) (the ice sheet at Gaussberg). In the case of Gaussberg the thinning was determined by comparison with the records of the German South Polar Expedition of $\mathrm{I}_{9 \mathrm{O}-\mathrm{O}}$, so that part at least of the thinning is definitely of this century.

\section{(b) Their amplitude}

The biggest temperature changes during the Pleistocene occurred in the neighborhood of the fluctuating ice sheets of Eurasia and North America, but away from these most evidence suggests that the temperature drop was smaller and roughly uniform. A survey of the problem by Flint (1957) suggests a world-wide drop of the order of $6^{\circ}$ to $8^{\circ} \mathrm{C}$. In the Southern Hemisphere, Willett (1950) has suggested that New Zealand at the Pleistocene temperature minimum was $6^{\circ} \mathrm{C}$. colder than today. As for Antarctica itself, from Sections IV (p. I84) and V of this paper, the general configuration of the ice sheet there is fairly stable. It is probable, therefore, that the temperature drop there also may have been of the order of $6^{\circ} \mathrm{C}$., and perhaps less than that in the center of the continent.

\section{The effect of the changes}

(a) Their effect on ice temperatures

The velocity of a cold ice sheet, and therefore its thickness, is depcndent on the temperature of its lowest layers (Nye, I959). Therefore, consider how a drop of $6^{\circ}$ C. at the surface of the Antarctic Ice Sheet would have affected its base. If the ice sheet were completely static, the vertical temperature profile in it would depend simply on the mean air temperature, the thermal diffusivity of ice and the geothermal heat flux, and would be linear. Pleistocene fluctuations of the mean air temperature would have been superposed on this profile in accordance with the equation for periodic heat flow:

$$
T_{r}=T_{o} \exp (-D \sqrt{\pi / \Delta P})
$$

If, in this equation, $T_{0}$, the range (amplitude $\times 2$ ) at the surface, is $6^{\circ} \mathrm{C}$.; $D$, the distance below the surface, is 4 , $000 \mathrm{~m}$.; $\Delta$, the thermal diffusivity of glacial ice, is $15 \times 10^{-3} \mathrm{~cm} . .^{2} / \mathrm{sec}$. (Cameron and Bull, r $96 \mathrm{I}$ ) and $P$, the period, is $100,000 \mathrm{yr}$, , then $\mathcal{T}_{r}$, the range at the base, is negligible. In other words, the base of a static ice sheet would have been effectively insulated 
from the temperature changes at the surface.* In practice, however, the Antarctic Ice Sheet is not static, and the temperature distribution in it is modified by the downward and outward movement of the cold surface snow and by frictional heat generated near the base. The effects of these "movement" factors have been considered by Robin (I955). In the context of this paper, which is concerned with temperature changes, it is clear that the downward movement of snow and ice must provide a cooling mechanism much more effective than the simple conduction evaluated above. A mathematical treatment of this movement cooling might be difficult; however, it follows from the argument on page 175 that each of the major Pleistocene temperature fluctuations lasted long enough for icc equal in volume to the ice sheet to have circulated through it several times over; therefore, it seems probable that movement cooling must have been able to transfer the $6^{\circ} \mathrm{C}$. cooling of the surface to the major part of the ice base. The most vigorous circulation must have been through the upper and outer parts of the ice sheet but simple conduction must have completed the transfer through its long-traveled lowest layers.

Robin's paper suggests one interesting reservation at this point. Robin showed that the smaller the accumulation is on an ice sheet then the smaller is the movement of cold into it and the greater the temperature difference that the geothermal flux can sustain between the base and the surface. For example, an ice sheet 3,000 $\mathrm{m}$. thick with an accumulation of only $4 \mathrm{~g} . / \mathrm{cm} .^{2}$ yr. should be $10^{\circ} \mathrm{C}$. warmer at the base than one with twice that accumulation. It will be seen in Section IV that one possible result of a drop in air temperature might have been a drop in accumulation. In such a case the atmospheric cooling might have been completely offset by a decrease in the movement cooling.

\section{(b) Their effect on velocity and thickness: the general case}

With the reservation above, it appears that the greater part of the ice sheet was probably cooled by approximately $6^{\circ} \mathrm{C}$. during each Pleistocene glacial stage in the Northern Hemisphere. These coolings must have caused at the ice base changes of temperature or wetness. which in turn must have produced changes in the value of $A^{-m}$ (see p. 177. It is now possible to proceed immediately to the main point of this section: that these changes have only a small effect on ice thickness. From equation (4)

$$
\begin{aligned}
& h^{2-1 m} \times A \\
& \text { or } \quad h \times\left(A^{-m-1} 2 m-1\right. \text {. }
\end{aligned}
$$

i.e. $h$ varies with only the minus one-ninth power of $A^{-m}$ in the case of a frozen base see p. 1,8 and the minus one-sixth power in the case of a melting base. $t$ This result deserves a fuller explanation. If the ice at the base is cooled it becomes less plastic and the velocity of the ice sheet is reduced. To maintain the velocity needed to dispose of the accumulation an increased shear stress is required. However. since the velocity is dependent on a high power of the shear stress, this increase need not be large. Moreover, an increase in the shear stress involves an increase in thickness: any given column of the ice sheet contains more material. and consequently the velocity need not be maintained at its original value.

(c) Their effect on ielocity and thickness: the Antarctic lic Sheat

Fquations (4) and (8) imply that $t^{m}$ is uniform under the whole ice sheet and that when this constant changes it changes everwhere by the same amount. In practice $A^{-r}$ is not uniform and during the Pleistocene it must have changed by different amounts in different parts of the ice sheet. To determine these amounts and their atmal effects on ice thickness. let us first imagine three different ice sheets. each uniform at the base, but each distinguished bu a different type of base.

* A. P. Cary personal communication has pointed out that pleistecone temperature fluctuations atas we: have been of step rather than wave form: however. this does not atfect the argument of this payer.

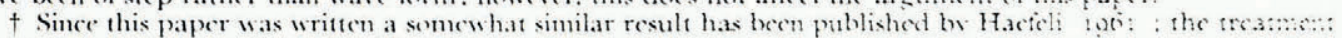
above remains note suitable for this paper. 
(i) Ice sheet $I$. Imagine an ice sheet with its base currently below the freezing point. A cooling of $6^{\circ} \mathrm{C}$. at the surface would cool the base by the same amount. In this ice sheet movement is purely by creep (see p. 178). It can be seen from equation (6) that a cooling of $6^{\circ} \mathrm{C}$. would reduce the creep rate by a factor of roughly 2 , and, by analogy with equation ( $\mathrm{I}$ ), this would act as a reduction in $A^{-m}$. Since the thickness of ice sheet I would be dependent on the minus one-ninth power of $A^{-m}$, it would increase by a factor of $\left(\frac{1}{2}\right)^{-1 / 9}$, i.e. $\mathrm{I} \cdot 08$. This result is of general interest; it implies that the thickness of any ice sheet which is frozen to its base is very insensitive to temperature changes, particularly in view of the thermal restraints discussed on page 183 .

(ii) Ice sheet 2. Imagine an ice sheet with its base currently at the melting point and with a small heat surplus available for basal melting. A cooling of $6^{\circ} \mathrm{C}$. at the surface would freeze the base and cool it to between $0^{\circ}$ and $-6^{\circ} \mathrm{C}$. Now, the mechanical behavior of ice close to the freezing point is not well known, and it is necessary to draw on a purely theoretical treatment by Steinemann (1958). (Steinemann's treatment concerns the reverse case to ours: a change from freezing to melting.) He argues that up to the melting point a temperature dependence of the Glen type applies (equation (6)). As soon as the melting point is reached additional heating by strain-work produces an increased soaking of the ice. In the case of a glacier the bottom $\mathrm{I} \mathrm{m}$. or so fills with water up to a volume fraction of $0_{1} \mathrm{I}_{5}$, at which point the water-filled pores interconnect and further melt water is pressed out and flows as free melt water. This soaking of the ice is accompanied, according to Steinemann, by an increase in plasticity much greater than that caused by any reasonable temperature changes below the melting point. He calculates, for example, for a shear stress of $1 \cdot 0$ bar, that the "wet" strain rate of "warm" ice is 15 times greater than the "dry" strain rate. Also, as the melting point is reached, movement mechanisms other than pure creep may develop. The "sliding" suggestion by Weertman (1957[a]) may be such a mechanism. It is difficult to predict how such mechanisms would affect the factor of 15 given above, but they are likely to increase it. Thus, in ice sheet 2 , a cooling would reduce $A^{-m}$ at least 15 times, and this would produce, from equation (8), an increase in ice thickness by at least $\mathrm{r} \cdot 6$ times. This is a large increase, but there is some field evidence that changes of this magnitude would occur. An increase of thickness by a factor of $\mathrm{x} \cdot 6$ involves an increase in surface slope by $\mathrm{I} \cdot 6$ and an increase in the basal shear stress by $2 \cdot 6$. Several workers have pointed out that shear stress differences of this order are probably associated with temperature or wetness differences at the ice base.

(iii) Ice sheet 3. Imagine an ice sheet with its base currently at the melting point, with a large heat surplus available for basal melting. A cooling of $6^{\circ} \mathrm{C}$. at the surface would merely reduce the amount of melt water produced. This might affect the velocity of the ice. However, once a warm ice base reaches the stage where water is being pressed out of it, then both creep and sliding mechanisms may have reached their maximum efficiency. Further melt water may only be squeezed out into a basal film, or, more probably, into subglacial channels. It is unlikely that these have any further "lubricating" effect. However, even if this assumption here is incorrect and wetness changes do produce velocity changes, these would still affect th? thickness only to the minus one-sixth or so power.

(iv) The Antarctic Ice Sheet. In summary, the base of the Antarctic Ice Sheet is probably divided into "patches" of three types, corresponding to the three imaginary ice sheets discussed above. The thickness changes in patches of types I and 3 were probably small, but in patches of type 2 they may have been large. Therefore, it is unfortunate that the geographical distribution and area of these patches are largely unknown, and are likely to remain so until a great deal of drilling and calculation have been carried out. For the purpose of calculating a Würm volume change for Section VII it has been assumed, which is probably reasonable, that patches of type 2 are scattered over a total of one-third of the ice sheet; but that only half of these patches would in practice be frozen by a cooling-this is because of the thermal restraints discussed below. 


\section{Thermal restraints on thickness changes}

The effect of temperature changes on the thickness of the ice sheet is further restrained by an interesting thermal mechanism. The temperature gradient in the atmosphere above the Antarctic Ice Sheet is roughly $\mathrm{I}^{\circ} \mathrm{C}$./ $100 \mathrm{~m}$., but the geothermal heat gradient at the base of the ice sheet is roughly $\mathrm{I}^{\circ} \mathrm{C}$. $/ 5^{\circ} \mathrm{m}$. $\left(\mathrm{I}^{\circ} \mathrm{C} . / 54 \mathrm{~m}\right.$. using for the flux the continental mean of $\mathrm{I} \cdot 23 \times \mathrm{IO}^{-6} \mathrm{cal} . / \mathrm{cm} .^{2} \mathrm{sec}$. (Jacobs and others, 1959, p. I02) and for the thermal conductivity of glacial ice, assumed independent of pressure, $6.6 \times 1 \mathrm{IO}^{-3} \mathrm{cal} . / \mathrm{sec} . \mathrm{cm} .{ }^{\circ} \mathrm{C}$. (Cameron and Bull, i96I)). Consequently, whatever the cooling by climatic change, and whatever the additional chilling due to the increased height of the ice sheet after thickening, these must soon be offset by the geothermal heat flow. Consider an assumed static part of the ice sheet $2,000 \mathrm{~m}$. thick with a surface temperature of $-4 \mathrm{I}^{\circ} \mathrm{C}$. and a basal temperature consequently raised by geothermal heat to $-1^{\circ} \mathrm{C}$. Let the surface and base be cooled by $6^{\circ} \mathrm{C}$. and the ice sheet consequently thicken. Whatever the thickening due to mechanical causes, the ice sheet is in any case limited to a thickness of $2,600 \mathrm{~m}$.; its surface temperature will then be $-41^{\circ}$ $-6^{\circ}$ (cooling) $-6^{\circ}$ (chilling due to increased height $)=-53^{\circ} \mathrm{C}$., which will be raised by the geothermal gradient $\left(\mathrm{I}^{\circ} \mathrm{C}\right.$. $/ 50 \mathrm{~m}$. for $2,600 \mathrm{~m}$.) back to the original $\mathrm{I}^{\circ} \mathrm{C}$. at the base. In practice, moreover, since the ice sheet is not static, the chilling due to the increase of height may not be as great as the atmospheric gradient suggests, if the increase is associated with less water vapor, less accumulation and less "movement" cooling (see Robin's theory on page I8I).

In summary, thickness changes due to temperature changes are limited (i) by mechanical factors, in particular by the relatively high value of $m$, and (ii) by the thermal factors discussed above. Since, in practice, these factors work together, their limiting effect must be considerable.

\section{The Effect of Changes in the Mass Budget}

The most familiar causes of glacial fluctuations are changes in the amount of accumulation and ablation, and this section is concerned with the effect of these in Antarctica. It appears that, however large the changes were, their effect was probably small.

\section{The changes}

It was argued in Section III that the primary climatic changes in Antarctica during the Pleistocene were air temperature reductions contemporaneous with those in the Northern Hemisphere. These must have reduced the already small amount of ablation by sublimation, evaporation and run-off. Since the grounded ice sheet lies chiefly in the accumulation zone today, the most important changes were probably those of accumulation.

\section{(a) Meteorological arguments}

The first effects of a cooling were probably a reduction in the amount of water vapor that the air above Antarctica could hold and a consequent reduction in accumulation. Of other possible effects, the most important must have been caused by changes in the vigor and pattern of the atmospheric circulation. Possibly the cooling reduced the vigor but, since the general configuration of the ice sheet is fairly stable (see p. I84 and 192), the pattern probably changed little. An analysis of all these effects was made in 1928 by Meinardus (reviewed by Simpson (1940)), whose calculations should be re-examined in the light of the now greatly increased meteorological data from Antarctica. For the reasons discussed on page 186, Meinardus was interested in the effect on accumulation of a warming of Antarctica. He found that an increase of temperature by $5^{\circ} \mathrm{C}$. and of the wind velocity by 24 per cent would have combined to increase the outflow of ice by a factor of 2. One might expect then that a cooling by $6^{\circ} \mathrm{C}$. with no major change in the wind would have reduced accumulation but by a factor of less than 2. A more precise result is not needed for this paper. 


\section{(b) Field evidence}

Such as it is, the field evidence confirms this result. The pit and core studies mentioned on page 180 have provided records of the accumulation in Antarctica for the last several hundred years. From that section, Antarctic temperatures during this period have probably risen by the order of $I^{\circ} \mathrm{C}$., from the eighteenth and nineteenth centuries climax of the Little Ice Age to the relative warmth of the twentieth century. However, no comparable increase in accumulation seems to have occurred. At "Wilkes Station" (S-2) there has been no major change in the accumulation since A.D. 1783 (Cameron and others, 1959). At the South Pole there has been no major change since A.D. 1530, apart from a minor twentieth century increase with a maximum in the 1920's (Giovinetto, 196o[a], [b]). (This increase correlates well with one recorded at "South Ice" (Lister, 1959), which Lamb (1959) thinks may be related to a world-wide intensification of the circulation.) At "Byrd Station" the accumulation has actually decreased very slightly since A.D. 1547 (Bender and Gow, I961).

\section{The effect of the changes}

(a) The effect in the "oases"

If ever the Pleistocene values of ablation and accumulation are determined more precisely, it will be useful to plot them as additional curves on Figure 2. Meanwhile, it seems from Figure 2 that, even after a two-fold decrease in accumulation, the total budget of the grounded ice sheet would have remained strongly positive, and that the greater part of the accumulation inland would have continued to reach the sea. There may have remained, in the higher parts of a narrow ablation zone, some small ice-free areas like those of today, where the boundary of the ice sheet may have changed slightly in response to the changes in ablation and accumulation. However, even if these changes were determined it would be very difficult to calculate the new boundary, for the following reasons. The effect of the ablation change might be assessed fairly accurately. The "accumulation" changes in the "oases" depend not only on the precipitation but also on what enters them as ice flow. To calculate the change in ice flow would require both a knowledge of the changed accumulation in the interior and an almost impossibly accurate knowledge of the subglacial relief there. Therefore, it will be even more difficult to reverse this procedure and to deduce from glacial geological evidence in the "oases" what were the changes in climate. Moreover, as will be seen in Section V, the limits of the ice sheet in the "oases" are in most cases practically independent of direct climatic control.

(b) The effect on the area and volume of the ice cover

It was noted on page 179 that, no matter what the supply of ice is on the grounded ice sheet, its limits (outside the few "oases") and therefore its area can be changed only by changes in sea-level. Also, from page I 77, the peripheral ice shelves are unlikely to spread beyond the continental shelf. Concerning the volume of the ice, although it was decided above that accumulation on the ice sheet may have been reduced by as much as a factor of 2, this does not mean that its thickness and volume were changed by a similar factor. As with temperature changes, the effect of (uniform) accumulation changes on the volume of the ice sheet can be estimated from equation (4), from which

$$
h \propto a^{1 /(2 m+1)},
$$

a dependence suggested earlier by Nye (1959). Assuming $m=2 \cdot 5$, a reduction of accumulation by 2 would have reduced the ice sheet only to $(\mathrm{I} / 2)^{1 / 6}$, i.e. to $9^{0}$ per cent of its original height. Some of this reduction might have been offset by an increase in precipitation on the center of the ice sheet as it dropped towards the new level.

\section{(c) Summary}

When the Antarctic Ice Sheet first formed cannot be discussed in this paper; this question may be solved by oceanographic work. Some authors appear to favor a Tertiary rather than 
a Pleistocene beginning. However, it is probable from the discussion on page 176 and above that once the ice sheet was formed it was never afterwards ablated away, at least by any of the climatic conditions of the Pleistocene. Also, it seems unlikely to be ablated away in the foreseeable future. It may be argued that conditions were periodically sufficient to ablate away the northern ice sheets; but those ice sheets ended chiefly on land, and the ablation at their edges must have been considerable, even as they grew. But in Antarctica there is no such intense ablation; as has been seen, only the surrounding sea is effective in this respect.

\section{Contemporary and short term fluctuations}

(a) Although it seems likely, it must not be assumed too soon that Antarctica is currently in a steady glacial or interglacial state. If the ice cover is still changing towards a steady state, the best evidence for this may lie in the areas of maximum ablation, which are the seaward ends of the ice shelves. Now, the American Geographical Society map of Antarctica shows that the frontal positions of the Ross and Filchner Ice Shelves have fluctuated considerably since they were first recorded. Since, as suggested by Swithinbank (1955), the general outline of these ice shelves suggests a stable position between rock anchors, it is likely that their fluctuations have been essentially random, influenced perhaps by such factors as tsunamis. In other parts of Antarctica, however, some ice shelves and ice cliffs do appear to be retreating and it is difficult to show that this retreat will not continue until the whole of Antarctica whose bedrock is below sea-level, e.g. a large part of West Antarctica, is covered only by ice shelves or sea ice; and not, as at present, by an ice sheet which is grounded only because of "horizontal forces" of the Robin type (see p. 179). It is unlikely that such a retreat is going to occur but the possibility that it has occurred in the past warrants a search, in areas such as the west side of the Ross Ice Shelf, for such evidence of a previous marine environment as wind-blown pectinids or the remains of large bird colonies.

(b) Another argument for contemporary change has becn put forward by Wexler (1960), who has suggested that the ice thickness in West Antarctica may be increasing as a result of a change in the atmospheric circulation pattern. In support of this suggestion it must be admitted that the surface of the ice sheet in West Antarctica is unusually low. For example, "Byrd Station", several hundred kilometers from the Ross Sea, is only I,500 m. above sea-level; from the east Antarctic profile of Figure 4 one would expect its elevation to be twice that. Basal shear stresses in West Antarctica (0.4 bar) (Bentley, I96I) are much lower than those apparently needed to dispose of the accumulation in East Antarctica. However, in view of the evidence given on pages 175 and 176 and of the vigorous ice streams reported from West Antarctica, the author is reluctant to accept the idea of a build-up there. Clearly the elevations and shear stresses in West Antarctica deserve a more careful study. Unfortunately, this cannot be undertaken here. Note that, if the ice thicknesses rather than the ice elevations in West Antarctica are considered (see the elevation and thickness maps in Bentley and Ostenso ( I96I )), then the disagreement with east Antarctic values is not so marked.

(c) A final argument for contemporary change is represented by the apparent surplus in the mass budget of Antarctica. Mellor (1959[b]) concludes that accumulation on the ice sheet and shelves together may currently be twice as great as the ablation from them. Now, it seems from page 184 that accumulation in Antarctica has been fairly constant since A.D. I530. Since, in the Northern Hemisphere at least, the years since then have included extremes of climate almost as great as any in the last 10,000 yr., it is possible that accumulation in Antarctica has been fairly constant for that period also. Clearly any appreciable build-up of the ice sheet cannot have been sustained for even a fraction of that time (which exceeds Nye's response time; see p. 175) without leaving any glacial geological, isostatic (see Section V) or eustatic evidence (Wexler, I96r). Therefore, if a build-up is in fact taking place, the most probable explanation of it lies in some short-term cyclic mechanism such as Robin (I 955) has suggested for Greenland. The particular thermal mechanism which Robin has suggested 
is unlikely to be operating in Antarctica; since most of the outlet glaciers there must already be melting at their bases, it is unlikely that the base of the whole ice sheet is rising in phase to a temperature which will trigger the release of a surplus. Also, it is unlikely that a build-up can be explained by the instability described by Weertman (196i). However, the problem of the mass surplus remains and there is clearly a need for more data to determine if this surplus is real.

\section{The Effect of Eustatic and Isostatic Changes}

\section{The paradox of Antarctic glaciation viewed in terms of the mass budget}

It was argued in Sections III and IV that the colder periods in the Pleistocene were contemporaneous in the Northern Hemisphere and Antarctica, and associated in the latter with reduced accumulation. Since ablation on the ice sheet of Antarctica is relatively unimportant (p. I 76), it seems that this reduced accumulation should have resulted in a less extensive glaciation. If this was the case, the glacial fluctuations of the Northern Hemisphere and Antarctica were out of phase. However, the field evidence of striae, erratics and raised beaches suggests that Antarctica is currently experiencing a glacial minimum in phase with that of the Northern Hemisphere.

This paradox has been a subject of discussion ever since it was noted by Scott (1905). The numerous attempts that have been made to resolve it have been summarized by Charlesworth (1957, p. 64r). Some authors, e.g. Nordenskjöld (r gog), have maintained that, at least in some areas, ablation changes were great enough to offset accumulation changes; however, this is unlikely to have been the case in the usual Antarctic situation, where a narrow ablation zone is traversed by ice draining a very large accumulation area. The solution suggested by Scott was that the previous greater ice cover of Antarctica was produced by greater accumulation, which could have been produced only by higher air temperatures. Authors from Brückner (1913) to Ewing and Donn (1958) have suggested that these higher air temperatures were associated either with northern interglacials or with the northern Climatic Optimum. Simpson (1940) and others have inferred from Scott's solution that greater glaciation everywhere in the world was associated with higher air temperatures.

It is this author's opinion that the correct solution of this problem was first outlined by Penck (1928), who argued that the sea forms the budgetary and mechanical limit of the Antarctic Ice Sheet and that when the world-wide sea-level was lowered during the Pleistocene the ice sheet consequently advanced by an amount which accounts for nearly all the evidence of a more extensive glaciation. The modern budgetary and mechanical data summarized in Section II make Penck's solution wholly convincing. Temperature and mass budget changes were of some importance, particularly in the cases of the Antarctic Peninsula and of isolated glaciers, but for the Antarctic Ice Sheet as a whole the major fluctuations were associated with fluctuations of sea-level.

\section{The effect of changes of sea-level}

To understand the nature of a glacial fluctuation caused by one of sea-level it must be remembered that, whereas a floating ice shelf is horizontal, a grounded ice sheet is always convex with a profile similar to that of Figure 3. Consider then the effect of a lowering of sea-level on, for example, the eastern half of the Ross Ice Shelf, where the elevations of the ice surface, ice base and sea floor were determined by the U.S. I.G.Y. traverse of $1957-58$. (These elevations are marked on the American Geographical Society map of Antarctica.) The current grounding line of the shelf is at roughly lat. $85^{\circ} \mathrm{S}$. The depth of water beneath it increases only slowly northwards and, if the level of the water were to be lowered $15^{\circ} \mathrm{m}$., this would advance the grounding line $550 \mathrm{~km}$. to roughly lat. $80^{\circ} \mathrm{S}$. Once the ice in this area was resting not on a relatively frictionless sea but on a rough rock bed, it would be unable to move forward until it became much thicker and developed a basal shear stress of the 
order of $\mathrm{I} \cdot \mathrm{o}$ bar. Accumulation on the old shelf would pile up until a convex profile similar to that of Figure 3 was reached; the configuration of this area of Antarctica would be changed completely.

Such a fluctuation of the ice sheet is illustrated in Figure 4, which is a modification of a similar figure in a paper by Voronov ( 1960 ). In this important paper Voronov attempts to reconstruct the ice sheet at its greatest extent. It appears that he envisages a lowering of sea-level by $300-500 \mathrm{~m}$. and a consequent ice advance averaging $190 \mathrm{~km}$. He shows how such

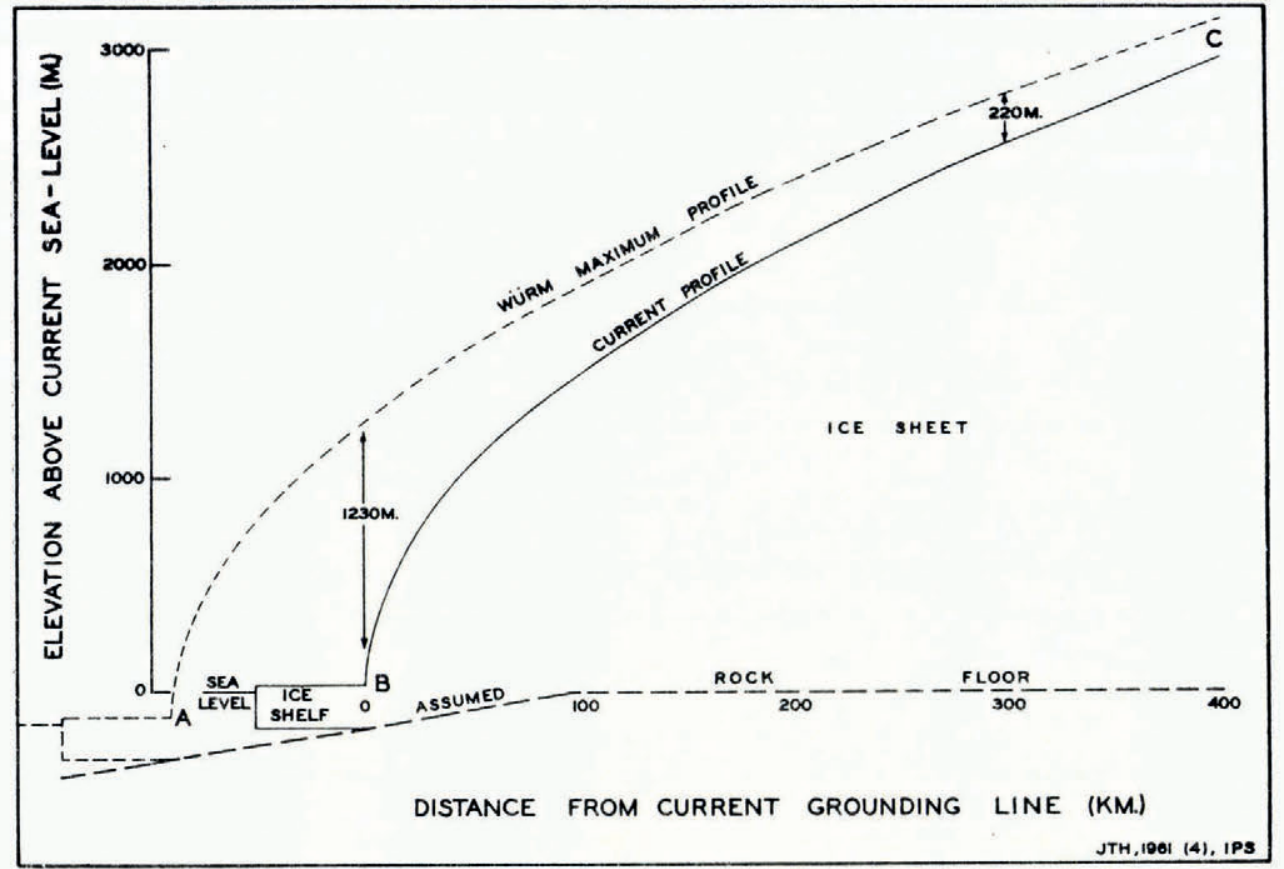

Fig. 4. Extension of the ice sheet by a sea-level drop of $150 \mathrm{~m}$.

an advance could account for the frequently postulated moraines on the continental shelf, and argues that it would have locked up in Antarctica an additional $12 \times 10^{6} \mathrm{~km} .{ }^{3}$ of ice, enough to lower the world-wide sea-level a further $30 \mathrm{~m}$. The chief differences between Voronov's figure and Figure 4 are that in the latter (a) the particular case of the ice shelves is illustrated (the similar advance in the case of ice cliffs can be easily envisaged), (b) smaller values for the lowering and advance are used, and (c) the two profiles are drawn according to equation (5). To facilitate drawing the figure, $h$ has been taken as the height above sea-level rather than above the rock floor.

\section{The amplitude of the changes}

(a) Eustatic and isostatic changes

A study of world-wide sea-level changes has been published recently by Fairbridge (I 96r). It appears from this that the sea-level in the past is unlikely to have been more than Ioo $\mathrm{m}$. (possibly $150 \mathrm{~m}$.; see below) below that in the present, at least since the Cretaceous. If this is so, then Voronov's apparent lowering of $300-500 \mathrm{~m}$., if it occurred, cannot be explained eustatically but only isostatically in terms of a relatively higher continental edge. Such might have been the situation at the climax of the first glaciation of the continent, perhaps for a few thousand years until the continental shelf sank under the weight of ice to the low level it has 
maintained probably ever since. Once the continental shelf sank to this level the subsequent position of the grounding line was presumably governed by sea-levels which apparently oscillated during the Pleistocene between highs in the northern interglacials and lows in the glacials. According to Fairbridge the lows became progressively lower until that in the Würm. Recent evidence by Ewing and others (1960) suggests that this Würm depression was roughly $\mathrm{I} 50 \mathrm{~m}$., and this value is used in Figure 4 and on page 189 .

(b) Relative change by ice shelf thickening

An additional relative lowering of sea-level may have been produced by a thickening of the ice shelves as a result of the lower temperatures associated with the northern glacial stages. This thickening can be investigated quantitatively. Weertman (1957[b] ) has established the following equation for the creep rate, $K$, of an ice shelf free to expand along the vertical and one horizontal axis:

$$
K=\left(\frac{1}{4} \rho_{I} g H^{2}\right)^{n}\left(\mathrm{I}-\rho_{I} / \rho_{\mathbb{W}}\right)^{n} /\left(\int_{0}^{H} A d y\right)^{n}
$$

where $\rho_{I}$ and $\rho_{W}$ are the densities of ice and sea-water, $g$ is the acceleration due to gravity, $H$ is the thickness of the shelf, and $n$ is probably 4.2 (see p. I 78). $A$ is a constant analogous to that on page $I_{7} 8$ and may, from there and from equation (6), be considered as the product of a constitution constant and a temperature constant $\exp (Q / R T n)$.

For $K$ substitute $a / H$, where $a$ is the accumulation rate. Equation (10) can then be solved for $H$ in terms of $T$ or, for interest, $a$. The integral is awkward; $A$ depends on $T$, but $T$ is hard to estimate (and is affected, incidentally, by $a$, by the Robin movement effect) and its distribution is dependent on the unknown $H$. However, consider temporarily the unreal case of a homogeneous, isothermal ice shelf. In that case the integral reduces to $A H$, and the following solutions are obtained:

$$
\begin{aligned}
& H \propto a^{1 /(n-1)} \\
& H \propto A^{n /(n+1)}=\text { a constant } \times \exp \{Q \mid R T(n+1)\}
\end{aligned}
$$

If equation ( 12 ) is evaluated for isothermal shelves at $0^{\circ}$ and $-30^{\circ} \mathrm{C}$., $H$ changes by only $=$. Since the temperature spreads in modern ice shelves (and presumably in Pleistocene oncs) are only a fraction of the above (for example, all shelves have approximately the same bottom temperature), it is clear that their thicknesses cannot be strongly dependent on temperaturc.

As a matter of interest this result draws attention to the problem of why, for example, parts of Maudheim Ice Shelf B (Robin, I 958) should be only $25^{\circ} \mathrm{m}$. thick while the greater part of the Ross Ice Shelf is $350 \mathrm{~m}$. thick (Crary, 1959). It appears from the above that differences in temperature and accumulation (note that this has to include bottom freezing or melting) are unlikely to account for all of this difference, especially since their effects in this case are probably in opposite directions. Now, inspection of Weertman's paper suggests another factor which might well be included in Robin's "horizontal forces". In addition to equation (I0) above, Weertman derived an equation for the creep rate, $K_{1}$, of an ice shelf free to expand along the vertical and both horizontal axes. $K_{\mathrm{I}} \approx{ }_{\mathrm{I}} \cdot{ }_{\mathrm{I}} K$. Now $K_{1}$ equals not $a / H_{\mathrm{t}}$ but $a / 2 H_{\mathrm{t}}$ (cf. Nye's (I 959) two- and threc-dimensional ice sheets). Solving both of Weertman's equations (for homogeneous, isothermal shelves) it is found that $H_{1}$ equals only $0 \cdot 86 H$. $H_{\mathrm{I}}$ probably applies to the outer part of the Maudheim shelf, but $H$ to the Ross Ice Shelf, constrained between Ross and Roosevelt Islands. Indeed, since the Ross Ice Shelf is not merely channeled but actually squeezed between these islands, the ratio of $H_{1}$ to $H$ may be even less.

\section{The effect in the Würm Glaciation}

(a) At the edge of the ice sheet

It appears then that during the Würm Glaciation the grounding line in Antarctica was 
$150 \mathrm{~m}$. lower than it is today, chiefly because of the eustatic effect. As a result, the main grounded ice sheet advanced by a distance which depended on the angle of the sea floor. From Law (196I) and assuming that the sea is $200 \mathrm{~m}$. deep at the present ice edge, this angle averages, very roughly, $0^{\cdot} \mathrm{I}^{\circ}$. This would have produced an average advance of $90 \mathrm{~km}$. These values are used in Figure 4. Now, it appears from Figure 4 that, because of the profile of an ice sheet, such a sheet need advance only a very small distance before its old margin is covered with a very great thickness of ice. Thus, the above-mentioned advance of $90 \mathrm{~km}$. may seem small (only 4 per cent of the present radius of the ice sheet), but it would have been enough to thicken the present ice margin by $1,230 \mathrm{~m}$. This is more than enough to account, for example, for the frequently-quoted previous glaciation of Gaussberg (373 m. high). In some cases, as was seen on page 186 , a flatter sea floor, such as that beneath the Ross Ice Shelf, would have produced an advance of as much as $500 \mathrm{~km}$. This in its turn would have produced an increase in ice thickness (subject to limitations discussed later in this section) of roughly $3,000 \mathrm{~m}$. Clearly the history of each part of the Antarctic periphery needs to be considered in the light of its own submarine topography.

(b) An isostatic restraint

The hypothetical advances discussed above might have been reduced considerably by isostatic effects. Consider a point at the ice margin where, by a combination of a $15^{\circ} \mathrm{m}$. sea-level drop and the sea-floor angle, an advance of $13.5 \mathrm{~km}$. took place. From equation (5) the additional thickness of the ice sheet at its old margin would be $545 \mathrm{~m}$., which, if isostatic compensation were locally perfect, would depress the rock beneath by $545 \mathrm{~m}$. multiplied by the density of ice and divided by the density of the mantle; that is by $150 \mathrm{~m}$.; which would completely counteract the effect of the eustatic drop. In practice such perfect compensation is not realized, for a number of reasons. First, since the compensation is spread over a wide area, the average additional thickness rather than that at one point should be considered. Secondly, compensation is rarely complete, because the shear strength of the crust is consideraable. Indeed, at first sight it seems unlikely that a disturbance only $90 \mathrm{~km}$. across should have any isostatic effect at all. However, since the other dimension of this disturbance is essentially ${ }_{1} 5,000 \mathrm{~km}$. (the circumference of the continent) a limited adjustment might be expected. Thirdly, there is a time lag between loading and compensation, although this should be small compared with the periodicity of the fluctuations.

At present, after the $\mathrm{W}$ ürm Glaciation, it is possible to study this isostatic restraint in the reverse direction only: as the rebound of the land reduces the relative post-glacial rise of sealevel. Evidence for the rebound is provided by the raised beaches reported from every coastal location in Antarctica, and possibly by the coastal gravity deficiency reported by Ushakov and Lazarev (1959). Evidence for its limited amplitude is provided bv the fact that the maximum elevation of these beaches is everywhere measured in tens of meters rather than in hundreds, as in Europe and North America.

\section{(c) At the center of the ice sheet}

It will be noticed on Figure 4 that the increase in ice thickness produced by an advance becomes much less as one goes inland. This is a point which has been overlooked by several authors who, for example, have taken the evidence that the ice in Victoria Land was once $1,200 \mathrm{~m}$. thicker to mean that the ice over the whole continent was that much thicker. This has led them to overestimate the volume of additional ice involved in glacial maxima. It appears from this section and from Sections III and IV that, once it was established there, the ice in central Antarctica did not fluctuate in thickness by any appreciable amount at all. A confirmation of this argument is provided by the preliminary gravity results from Antarctica: approximate isostatic equilibrium has been reported for both West Antarctica (Bentley and others, I960) and East Antarctica (Sorokhtin and others, 1960). In view of what is now known of the structure of Antarctica, the negative Bouguer anomaly reported along the route of the 
Commonwealth Trans-Antarctic Expedition (Pratt, 1959) is perhaps best interpreted as a normal continental rather than isostatic effect.

\section{The effect before the Würm Glaciation}

It follows from this section that our theoretical knowledge of the glacial fluctuations of Antarctica depends on our knowledge of eustatic fluctuations. This is controversial even for the Würm Glaciation, and for the time before that our knowledge is very sparse indeed. However, it is likely that the Würm low was the lowest in a series of oscillations, in which the highest level, according to Fairbridge (196I), may have been I0o m. above present sea-level. Now, just as low sea-levels produced expansions of the ice sheet, higher sea-levels must have produced contractions of it. The magnitude of these contractions can be calculated in the same way as that of the expansions. It follows from the argument on page 185 that these contractions may have been important, especially in the area of the Ross Ice Shelf and West Antarctica.

\section{Applications of this section to particular problems of glacial geology}

(a) The coastal "oases"

It follows from this section that the ice margin in an "oasis" may be determined not so much by climatic factors as by the need for the margin to be in mechanical equilibrium with surrounding glaciers whose limit is determined by sea-level. This point is illustrated below by a simplified treatment of some aspects of the glacial geology of the Windmill Islands, of which a map and general description have been published by Hollin and Cameron (I96I). (Climatic factors were not completely unimportant in the glacial history of the Windmill Islands; the author hopes to discuss their effects in a future paper; but they were almost certainly overshadowed by the sea-level effect.)

(i) The Windmill Islands and peninsulas are currently ice-free chiefly because they are rela. tively high, so that the ice sheet inland from them drains more easily via the lower areas to the south-west and north-east, where its limit is determined by sea-level. To the north of the Windmill Islands the sea is extremely shallow (the Petersen Bank) and when the sea-level was lowered during the Würm Glaciation the ice sheet probably advanced across this bank for several tens of kilometers (p. i 86). From equation (5) the ice must have been of the order of $\mathrm{I}, \mathrm{OOO} \mathrm{m}$. thick in the neighborhood of the present Balaena Islands: a height it could not have maintained without covering the Windmill Islands to the south.

(ii) Conversely, at the end of the Würm Glaciation the deglaciation of the Windmill Islands was probably governed not so much by the climatic improvement as by the post-glacial rise of sea-level. Probably this rise began about I8,00o yr. B.P. and probably the retreat of the Antarctic Ice Sheet began at about the same time. From Fairbridge ( I96I), the main rise was not completed, however, until about 6,000 yr. B.P., which, ignoring various time lags, must have been the date at which the ice sheet assumed the general configuration it has today. Subsequent modifications to this were provided by the "ablating down" process (see p. 175) and by isostatic rebound.

(iii) It follows from the above that if the deglaciation process was still continuing as recently as 6,ooo yr. B.P., then shells, whalebone, etc. from the subsequent raised beaches will tend to be younger than those from Northern Hemisphere beaches, whose emergence was governed more directly by climatic factors. In fact, all the Antarctic radiocarbon dates known to the author do post-date 6,000 yr. B.P. Clearly these low ages should not be mistaken for evidence (see p. I 86 and I93) that the deglaciation of Antarctica has been produced by an accumulation decrease following the Climatic Optimum. If the search areas are chosen carefully, it should be possible to find in Antarctica post-glacial material as old as any in the Northern Hemisphere. Promising areas would be bird rookeries on high nunataks, where a useful dating material might be the thick, durable layers of oily "bird-spittle". (The author is grateful to A. Heine of the New Zealand Geological Survey for drawing his attention to this material.) 
(iv) Frequently, in the Windmill Islands and elsewhere (Hollin and Cameron, I96 I), current ice cliffs abut against islands and peninsulas possessing undisturbed sequences of raised beaches. This argues strongly for, although it does not prove, a current advance of the ice. Originally this advance was thought by the author to be a mass budgetary phenomenon, possibly related to the Little Ice Age of the Northern Hemisphere but with a lag due to the size of Antarctica. Now, however, it seems more likely that the advance is a secondary effect of the isostatic rebound that produced the raised beaches; the rebound had the effect of relatively lowering sea-level; the budgetary and mechanical limit of the sea was removed; and the ice sheet moved forward a little.

\section{(b) The Ross Sea area}

It was seen on page 187 that a fall in sea-level of $\mathrm{I} 50 \mathrm{~m}$. would ground the eastern half of the Ross Ice Shelf. Such a grounding would eliminate the ablation by bottom melting which probably occurs there, and a colder and shallower Ross Sea to the north would probably be capable of less calving action at the shelf edge. On budgetary grounds, therefore, there is a strong possibility that the shelf would advance northwards towards the edge of the continental shelf (roughly a line between Capes Adare and Colbeck). As it advanced it would ground on the large and numerous banks, with a depth of less than 200 fathoms $(366 \mathrm{~m}$.), on the Ross Sea floor (see U.S. Navy Hydrographic Office Chart No. 6636). Where it grounded one would expect to find "ice hills" (Robin, I958), similar to the present Roosevelt Island, with roughly parabolic profiles. Possibly, the horizontal forces at these ice hills would be sufficient (as in West Antarctica; see p. 185) to ground the shelf even where the water is relatively deep. On this question one can refer to the parallel case of the Filchner Ice Shelf: a large area of that shelf manages to float inland from Berkner Island, but it is over $600 \mathrm{~m}$. thick, which means that it would be well grounded if it were in a Ross Sea $150 \mathrm{~m}$. lower than today. In theory, it appears that a general grounding of the Ross Ice Shelf could have taken place, particularly at the beginning of the Antarctic glaciation and during the Würm; in practice, however, the isostatic restraint could have restricted this grounding to the banks. The history of the Ross Sea may be contained in its sediments and recent investigations of these have been made by Thomas (1960). (Thomas claims that there has been no ice shelf in McMurdo Sound for 33,00o yr.; this author feels that a more adequate dating is needed to justify this conclusion.)

Consider some probable effects of a grounding of the Ross Ice Shelf. First, the appearance of the area would be different; horizontal surfaces would be replaced by convex ones which would rise steeply to one, two or three thousand meters. Secondly, the "dry valleys" of Victoria Land would be filled not so much by the frequently postulated "ice floods" from the interior to the west (though such may have occurred) as by the intrusion of ice lobes from the grounded shelf to the east.* Thirdly, at its greatest development a Ross Ice Sheet might deflect from West Antarctica warm, moist air which today reaches it, and inhibit the katabatic winds which are responsible for the currently great ablation in the dry valleys. Finally, with a warming climate and rising sea-level, one might expect the retreating ice sheet and ice shelf to leave behind it relict masses of ice, some of them stranded by isostatic rebound. Various workers have suggested that the Lady Newnes Ice Shelf and the Wilson Piedmont Glacier originated as such relicts.

\section{The Effect of Changes in Topography}

The above climatic and sea-level fluctuations, and the response mechanism described by Nye (1959), provide the glacial geologist with numerous possible explanations for limited glacial advances and retreats in any particular area. However, it appears from Sections III, IV and $\mathrm{V}$ that on the whole the changes produced in this way are likely to have been small, especially in the last few hundred thousand years and in the center of Antarctica. It must be

* Since this paper was written actual field evidence for such intrusions from the cast has been reported by Nichols ( $196 \mathrm{r}[\mathrm{b}])$. 
remembered, therefore, that empty cirques, striae, erratics, etc. can be accounted for by factors other than the above. These other factors can be called topographic. First, the growth of the ice sheet has effectively changed the topography; for example, West Antarctic mountains which were once in maritime situations and presumably received heavy snowfalls are isolated now in the relatively arid center of the ice sheet. Secondly, the changing isostatic compensation of the ice sheet has produced topographic effects, such as the depression of the continental shelf mentioned on page I 87. Thirdly, as Roots (1952) and Swithinbank (1959) have pointed out, reductions in ice level in mountain areas may have been produced merely as a result of the progressive glacial erosion of spillways and drainage valleys. Finally, it is possible that major changes in the configuration of the rocks of the continent may have occurred while it has been glaciated. In particular, the emplacement of the McMurdo Volcanics (Harrington, 1958) may have involved large changes in the topography of the Ross Sea area and West Antarctica.

\section{Conclusion}

\section{Summary of results}

We see now that both temperature and sea-level effects keep the fluctuations of the Antarctic ice cover in phase with those of the northern ice sheets.* The fluctuations are likely to have been small during most of the Pleistocene; during the most recent Würm maximum the ice sheet probably advanced by an average of $90 \mathrm{~km}$.; at times in the early Pleistocene or Tertiary the ice sheet may have been both larger than in the Würm, if Voronov's hypothesis is correct, and smaller than now, if the higher sea-levels referred to on page rgo were important.

Of more than Antarctic interest are the volume changes involved in these fluctuations. The current volume of the grounded Antarctic Ice Sheet is roughly $30 \times 10^{6} \mathrm{~km} .^{3}$, assuming an area of $13 \times 10^{6} \mathrm{~km} .{ }^{2}$ and a mean thickness of $2,300 \mathrm{~m}$. Voronov calculated for "the epoch of maximum glaciation" an additional volume of $12 \times 10^{6} \mathrm{~km} .{ }^{3}$ by multiplying the circumference of the ice sheet by his equivalent of the area $A B C$ in Figure 4. Since Voronov's figure depends in theory on an isostatically higher shelf and in practice on various submarine banks actually being end moraines, his figure should be taken as an absolute maximum. For the Würm Glaciation this author suggests the following very approximate values for the change in ice volume:

Thickening due to temperature reduction Thinning due to accumulation reduction

$$
\begin{aligned}
& <3.0 \times 10^{6} \mathrm{~km}^{3} \\
& <3.0 \times 10^{6} \mathrm{~km} .^{3}
\end{aligned}
$$

Extension and thickening due to sea-level lowering (assuming no isostatic restraint)

(a) $A B C$ (Fig. 4) $\times$ periphery of $15,000 \mathrm{~km}$.

(b) Extra for Ross and Weddell Seas

Total increase in volume:

$4 \cdot 0 \times 10^{6} \mathrm{~km} \cdot{ }^{3}$

$\mathrm{I} \cdot 5 \times 10^{6} \mathrm{~km} \cdot{ }^{3}$

between 2.5 and $8.5 \times 10^{6} \mathrm{~km} .^{3}$

Ignoring isostatic effects this additional cover would have produced an additional lowering of sea-level of between 6 and $21 \mathrm{~m}$. The author feels that the lower value is the more realistic of the two.

\section{The need for more data}

The results above are based on the most straightforward interpretation of the currently available field data. Since these data are so scanty it is not very difficult to fit them into other interpretations. For example, it was decided chiefly on theoretical grounds that Antarctic

* It should be noted that this sentence is not an endorsement of Harrington and Speden's (1960) tentative correlation of Beacon Valley and New Zealand moraines. On this matter the author's position remains that expressed in subsequent correspondence in the Journal of Glaciology. On the basis of this paper the predominant factor in the Recent history of Beacon Valley is likely to have been the sea-level rise between 18,000 and 6,000 yr. ago. 
glacial maxima are in phase with northern ones. It was seen in Section IV that this simple picture might conceal contemporary or short-term cyclic fluctuations. However, it is also possible to argue for "out-of-phase" fluctuations. In such an argument the ice sheet would be growing towards, or be already at, a maximum produced by an accumulation increase consequent on the deglaciation of the Northern Hemisphere. Striae and erratics would date from earlier maxima, and raised beaches would represent an upward bulge peripheral to a sinking of central Antarctica. The weaknesses of this interpretation will be clear to anyone who tries to fit into it all the field and theoretical data assembled in this paper, but the possibility of it should be borne in mind by field workers, who should be alert for means of proving or disproving it.

\section{The problem of causes}

It appears from the above that the fluctuations of the Antarctic ice cover are essentially dependent on those of the northern ice sheets. However, this proves nothing about the causes of glaciation or glacial fluctuations, which may be either world-wide or localized. Moreover, because Antarctic fluctuations are dependent on northern ones, the continent is a rather unsuitable area for the investigation of causes. Suppose, for example, that Milankovitch is correct and Antarctica is affected by radiation fluctuations out of phase with those in the Northern Hemisphere; their effect is likely to be lost in the larger eustatic and temperature effects dependent on Northern Hemisphere changes. In view of the limitations of Antarctica in this connection, it may be pointed out that an assessment of the solar rôle in glaciation may be obtained more efficiently by comparisons of recent stratigraphy on the Earth and on the planet Mars. Obviously, in view of current plans, some of cur thinking should be directed toward such comparisons.

\section{AgKnowledgements}

This paper was written while the author was employed at the Institute of Polar Studies, The Ohio State University, under National Science Foundation grant G-148 8 for the analysis of data from the U.S. I.G.Y. program. He thanks all those members of the U.S. Antarctic Research Program and the Institute of Polar Studies who have contributed data or criticism to this paper. In particular thanks are extended to Dr. C. Bull and Dr. J. Weertman for reading the manuscript.

MS. received 26 September 1961

\section{REFERENCES}

Ahlmann, H. W. 1948. Glaciological research on the North Atlantic coasts. London, Royal Geographical Society. (R.G.S. Research Series, No. 1.)

Avsyuk, G. A., and others. I956. Geograficheskiye nabludeniya v antarkticheskom "oazise" [Geographical observations in an Antarctic "oasis"]. [By] G. A. Avsyuk, K. K. Markov [and] P. A. Shumskiy. Izvestiva Vsesoyuznogo Geograficheskogo Obshchestva [News of the All-Union Geographical Society], Tom 88, Vyp. 4, p. 316-50. [English translation published by U.S.S.R. Academy of Sciences, Moscow. 69 p.]

Bauer, A. r 96 I. Nouvelle estimation du volume de la glace de l'indlandsis antarctique. Union Géodésique et Géophysique Internationale. Association Internationale d'Hydrologie Scientifique. Assemblée générale de Helsinki, 25-7-6-8 1960. Colloque sur la glaciologie antarctique, p. 19-23.

Bender, J. A., and Gow, A. J. 1961. Deep drilling in Antarctica. Union Géodésique el Géophysique Inlernationale. Association Internationale d'Hydrologie Scientifique. Assemblée générale de Helsinki, 25-7-6-8 196o. Colloque sur la glaciologie antarctique, p. $132-41$.

Bentley, C. R. 1961. Glaciological results of traverse geophysical observations in West Antarctica. Union Géodésique et Géophysique Internationale. Association Internationale d'Hydrologie Scientifique. Assemblée générale de Helsinki, 2.5-76-8 1.96o. Colloque sur la glaciologie antarctique, p. 123.

Bentley, C. R., and Ostenso, N. A. r961. Glacial and subglacial topography of West Antarctica. Journal of Glaciolog), Vol. 3, No. 29, p. 882-91 I.

Bentley, C. R., and others. 1960. Structure of West Antarctica, by C. R. Bentley. A. P. Crary, N. A. Ostenso and E. C. Thiel. Science. Vol. 131, No. 3394, p. 131-36. 
Brückner, E. 1913. Die Schneegrenze in der Antarktis. Zeitschrift für Gletscherkunde, Bd. 7, Ht. 4, p. $276-79$.

Bull, C., and others. I962. Quaternary glaciations in southern Victoria Land, Antarctica, by C. Bull, B. C. McKelvey and P. N. Webb. Fournal of Glaciology, Vol. 4, No. 31, p. 63-78.

Butkovich, T. R., and Landauer, J. K. 1958. The flow law for ice. Union Géodésique et Géophysique Internationale. Association Internationale d'Hydrologie Scientifique. Symposium de Chamonix, 16-24 sept. 1958, p. 318-27.

Cameron, R. L., and Bull, C. Unpublished. Thermal diffusivity and thermal conductivity of glacial ice at Wilkes Station, Antarctica. [Paper presented at the tenth Pacific Science Congress of the Pacific Science Association, Honolulu, i96r.]

Cameron, R. L., and others. I959. Wilkes Station glaciological data 1957-1958, by R. L. Cameron, O. Loken and J. R. T. Molholm. Ohio State University Research Foundation. Report $825^{-1}-$ Part III.

Charlesworth, J. K. 1957. The Quaternary era, with special reference to its glaciation. London, Edward Arnold. 2 vols.

Crary, A. P. 1959. Oversnow traverses from IGY Little America Station. Transactions. American Geophysical Union, Vol. 40, No. 3, p. 311-15; IG Y Bulletin (Washington, D.C.), No. 27, p. 1 I-1 $^{1}$.

Dolgushin, L. D. 1958. Les particularités morphologiques essentielles et les régularités des mouvements des glaciers de la marge de l'Antarctide orientale (d'après les observations (les relevés) dans la région des travaux de la partie continentale de l'Expédition Complexe Antarctique de l'Académie des Sciences de l'URSS). Union Géodésique et Géophysique Internationale. Association Internationale d'Hydrologie Scientifique. Symposium de Chamonix, I6-24 sept. 1958 , p. I I I-24.

Dolgushin, L. D. I $96 \mathrm{I}$. Zones of snow accumulation in eastern Antarctica. Union Géodésique et Géophysique Internationale. Association Internationale d'Hydrologie Scientifique. Assemblée générale de Helsinki, 25-7-6-8 rg6o. Colloque sur la glaciologie antarctique, p. $63-70$.

Ewing, M., and Donn, W. L. 1956. A theory of ice ages. Science, Vol. 123, No. 3207, p. 1061-66.

Ewing, M., and Donn, W. L. I958. A theory of ice ages. II. Science, Vol. 127, No. 3307, p. I I $59-62$.

Ewing, M., and others. 1960. Revised estimate of Pleistocene ice volume and sea-level lowering, by M. Ewing, W. L. Donn and W. Farrand. Bulletin of the Geological Society of America, Vol. 7I, No. 12, Pt. 2, p. 186 I.

Fairbridge, R. W. $196 \mathrm{r}$. Eustatic changes in sea-level. Physics and Chemistry of the Earth, Vol. 4, p. 99-185.

Flint, R. F. [1957.] Glacial and Pleistocene geology. New York, John Wiley and Sons.

Gage, M. 1961. New Zealand glaciations and the duration of the Pleistocene. Fournal of Glaciology, Vol. 3, No. 29, p. $94^{\circ}-43$.

Giovinetto, M. B. 1960[a]. South Pole glaciological data 1958. Ohio State University Research Foundation. Report 825-2-Part IV.

Giovinetto, M. B. $1960[\mathrm{~b}]$. Glaciological studies at the South Pole Station. Union Géodésique et Géophysique Internationale. Monographie No. 5, p. 64. [Abstract of paper presented at Simposio Antartico Argentino, Buenos Aires, November 1959.]

Glen, J. W. 1955. The creep of polycrystalline ice. Proceedings of the Royal Society, Ser. A, Vol. 228, No. 1175 , p. $5^{19-38 .}$

Glen, J. W. 1958. The mechanical properties of ice. I. The plastic properties of ice. Advances in Physics, Vol. 7, No. 26 , p. $254-65$.

Goldthwait, R. P. In press. Regimen of an ice cliff on land in northwest Greenland. [Paper presented at XIXth Geographical Congress, Norden, I96o.]

Haefeli, R. 1961. Contribution to the movement and the form of ice sheets in the Arctic and Antarctic. Journal of Glaciology, Vol. 3, No. 30, p. $1133-51$.

Harrington, H. J. 1958. Nomenclature of rock units in the Ross Sea region, Antarctica. Nature, Vol. 182, No. 4631 , p. 290.

Harrington, H. J., and Speden, I. G. 1960. Recent moraines of a lobe of the Taylor Glacier, Victoria Land, Antarctica. Journal of Glaciology, Vol. 3, No. 27, p. 652-53. [Letter.]

Hollin. J. T., and Cameron, R. L. I961. I.G.Y. glaciological work at Wilkes Station, Antarctica. Journal of Glaciology, Vol. 3, No. 29, p. $833-43$.

Jacobs, J. A., and others. 1959. Physics and geology, by 7. A. Jacobs, R. D. Russell and f. Tuzo Wilson. Toronto, McGrawHill.

Lamb, H. H. 1959. (In Lister, H., and Pratt, G. Geophysical investigations of the Commonwealth Trans-Antarctic Expedition. Geographical Journal, Vol. 125, Pt. 3-4, [discussion,] p. 355-56.)

Law, P. G. 1961. The edge of the Antarctic continental shelf. Polar Record, Vol. 10, No. 67, p. 415.

Lister, H. 1959. Geophysical investigations of the Commonwealth Trans-Antarctic Expedition. I. Geographical Journal, Vol. 125, Pt. 3-4, p. 343-51.

Loewe, F. 1955. The depth of crevasses. Fournal of Glaciology, Vol. 2, No. 1 7, p. 5 1 1-1 2. [Letter.]

Loewe, F. 1957. (In Rooy, M. P. van, ed. Meteorology of the Antarctic. Pretoria, Weather Bureau, p. 88.)

Mellor, M. 1959[a]. Variations of the ice margins in East Antarctica. Geographical Journal, Vol. 125, Pt. 2, p. $230-35$.

Mellor, M. 1959[b]. Mass balance studies in Antarctica. Journal of Glaciology, Vol. 3, No. 26, p. 522-33.

Mellor, M. 1960. Temperature gradients in the Antarctic ice sheet. Fournal of Glaciology, Vol. 3, No. 28 , p. 773-82.

Nichols, R. L. I961[a]. Tufts College-National Science Foundation Antarctic Expedition, 1959-6o. Polar Record, Vol. 10, No.67, p. 401 .

Nichols, R. L. 1961[b]. Multiple glaciation in the Wright Valley, McMurdo Sound, Antarctica. Abstracts of symposium papers, tenth Pacific Science Congress of the Pacific Science Association, Honolulu, 196r, p. 317.

Nölke, F. 1932. Die Antarktis während der Eiszeit. Zeitschrift für Gletscherkunde, Bd. 20, Ht. 1, p. 45-51.

Nordenskjöld, O. rgog. Einige Beobachtungen über Eisformen und Vergletscherung der antarktischen Gebicte. zeitschrift für Gletscherkunde. Bd. 3, Ht. 5, p. 32 I-34.

Nye, J. F. 1952. The mechanics of glacier flow. Fournal of Glaciologv, Vol. 2, No. 12, p. 82-93.

Nye, J. F. 1959. The motion of ice sheets and glaciers. Fournal of Glaciolog,, Vol. 3, No. 26, p. 493-507. 
Nye, J. F. 1960. The response of glaciers and ice-sheets to seasonal and climatic changes. Proceedings of the Royal Society, Ser. A, Vol. 256, No. 1287 , p. 559-84.

Penck, A. 1928. Die Ursachen der Eiszeit. Sitzungsberichte der Preussischen Akademie der Wissenschaften zu Berlin, Phys.-Math. Kl., 1928, No. 6, p. 76-85.

Péwé, T. L. 1960. Multiple glaciation in the McMurdo Sound region, Antarctica-a progress report. Journal of Geology, Vol. 68, No. 5, p. 498-514.

Pratt, G. 1959. Geophysical investigations of the Commonwealth Trans-Antarctic Expedition. II. Geographical Fournal, Vol. 1 25, Pt. 3-4, p. 351-54.

Robin, G. de Q. ${ }^{1} 955$. Ice movement and temperature distribution in glaciers and ice sheets. Fournal of Glaciology, Vol. 2, No. I 8, p. 523-32.

Robin, G. de Q. 1958. Glaciology. III. Seismic shootings and related investigations. Norwegian-British-Swedish Antarctic Expedition, 1949-52. Scientific Results (Oslo, Norsk Polarinstitutt), Vol. 5, p. I-1 34.

Roots, E. F. 1952. The Norwegian-British-Swedish Antarctic Expedition 1949-52. Science News (Harmondsworth, Penguin Books), 26, p. 9-32.

Scott, R. F. 1905. Results of the National Antarctic Expedition, I. Geographical Journal, Vol. 25, No. 4, p. 353-73.

Shumskiy, P. A. 1957. Glaciological and geomorphological reconnaissance in the Antarctic in 1956. Journal of Glaciology, Vol. 3, No. 21, p. 54-6i .

Shumskiy, P. A. 1959. Sovetskiye glyatsiologicheskiye issledovaniya v Antarktide [Soviet glaciological investigations in Antarctica]. Akademiya Nauk SSSR. Mezhduvedomstvennyy Komitet po Provedeniyu Mezhdunarodnogo Geofizicheskogo Goda. Sbornik Statey. IX $i$ XII Razdely Programmy MGG (Glyatsiologiya $i$ Seysmologiya) [Academy of Sciences of the U.S.S.R. Interdepartmental Committee for Participation in the International Geophysical Year. Collected Papers. Sections IX and XII of the I.G.Y. Programme (Glaciology and Seismology) ], No. 2, p. 77-83.

Shumskiy, P. A. 1960. Osnovnyye rezul'taty issledovaniya antarkticheskogo lednikovogo pokrova [Main results of study of the Antarctic ice sheet]. (In Treshnikov, A. F., ed. Vtoraya kontinental'naya ekspeditsiya $195^{6-195^{8}}$ gg . Nauchnyye rezul'taty [Second continental expedition, 1956-58. Scientific results]. Leningrad, Izdatel'stvo "Morskoy Transport" ["Morskoy Transport"' Publishing House], p. $126-70$. [Numbered "9".])

Simpson, Sir G. C. 1940. Possible causes of change in climate and their limitations. Proceedings of the Linnean Society of London, 152 nd Session, Pt. 2, p. 190-2 19.

Sorokhtin, O. G., and others. 1960 . Metodika i osnovnyye rezul'taty seysmicheskikh i gravimetricheskikh issledovanii stroyeniya vostochnoy Antarktidy [Methods and principal results of seismic and gravimetric studies of the structure of eastern Antarctica]. [By] O. G. Sorokhtin, O. K. Kondrat'yev [and] Yu. N. Avsyuk. Izvestiya Akademii Nauk SSSR. Seriya Geofizicheskaya [News of the Academy of Sciences of the U.S.S.R. Geophysical Series], 196o, No. 3, p. 396-401. [Translation in Bulletin of the Academy of Sciences of the U.S.S.R. Geophysical Series, 1960, No. 3, p. $265-68$.

Steinemann, S. 1958. Thermodynamics and mechanics of ice at the melting point. Union Géodésique el Géophysique Internationale. Association Internationale d'Hydrologie Scientifique. Symposium de Chamonix, I6-24 sept. 1958, p. 254-65.

Swithinbank, C. W. M. 1955. Ice shelves. Geographical Journal, Vol. 12 1, Pt. 1, p. 64-76.

Swithinbank, C. W. M. 1959. Glaciology. I. The morphology of the inland ice sheet and nunatak areas of western Dronning Maud Land. Norwegian-British-Swedish Antarctic Expedition, 1.949-52. Scientific Results (Oslo, Norsk Polarinstitutt), Vol. 3, D, p. 97-117.

Thomas, C. W. 1960. Late Pleistocene and recent limits of the Ross Ice Shelf. Journal of Geophysical Research, Vol. 65 , No. 6, p. $1789-92$.

Ushakov, S. A., and Lazarev, G. Ye. 1959. Ob izostaticheskom progibanii zemnoy kory v Antarktide pod tyazhest'yu ledovoy nagruzki [Isostatic depression of the Earth's crust in Antarctica under the weight of the ice load]. Doklady Akademii Nauk SSSR [Reports of the Academy of Sciences of the U.S.S.R.], Tom 129, No. 4, p. 785-88.

Vyalov, S. S. 1958 . Regularities of glacial shields movement and the theory of plastic viscous flow. Union Géodésique et Géophysique Internationale. Association Internationale d'Hydrologie Scientifique. Symposium de Chamonix, I6-24 sept. 1958, p. 266-75.

Voronov, P. S. 1960. Opyt restavratsii lednikovogo shchita Antarktidy epokhi maksimal'nogo oledeneniya Zemli [Attempt to reconstruct the ice sheet of Antarctica at the time of maximum glaciation on Earth]. Informatsionnyy Byulleten' Sovetskoy Antarkticheskoy Ekspeditsii [Information Bulletin of the Snviet Antarctic Expedition], No. 23 , p. $15^{-19}$.

Weertman, J. I957[a]. On the sliding of glaciers. Journal of Glaciology, Vol. 3, No. 21, p. 33-38.

Weertman, J. 1957 [b]. Deformation of floating ice shelves. Journal of Glaciology, Vol. 3, No. 21, p. $3^{8-42 .}$

Weertman, J. 1961. Stability of Ice Age ice sheets. Journal of Geophysical Research. Vol. 66, No. 1 1, p. 3783-92.

Wexler, H. 1959. A warming trend at Little America, Antarctica. Weather, Vol. 14, No. 6, p. 19 I-97.

Wexler, H. 1960. Geothermal heat and glacial growth. Journal of Glaciology, Vol. 3, No. 27, p. 654-57. [Letters.]

Wexler, H. 1961. Ice budgets for Antarctica and changes in sea-level. Journal of Glaciology, Vol. 3, No. 29, p. $867-72$.

Willett, R. W. 1950. The New Zealand Pleistocene snow line, climatic conditions and suggested biological effects. New Zealand Journal of Science and Technology, Sect. B, Vol. 32, No. 1, p. 18-48.

Yoshikawa, T., and Toya, H. 1957. Report on geomorphological results of the Japanese Antarctic Research Expedition, 1956-57. Antarctic Reiord, No. 1, p. 1-13. [In Japanese, with 3-page English abstract.] 